\title{
Panorama Económico in the context of the international visibility of scientific journals
}

\author{
ANDRÉS ESCOBAR-ESPINOZA ${ }^{1}$ \\ Universidad de Cartagena \\ aescobare@unicartagena.edu.co \\ GRACE ANGULO-PICO² \\ Universidad de Cartagena \\ gangulop@unicartagena.edu.co
}

\begin{abstract}
Assessment of scientific journals in the National Bibliographic Index Publindex represented a continuous improvement in terms of quality of national academic journals. Nevertheless, this process came along inconsistencies between national standards and international requirements (Rodriguez-Morales, 2014). To some extent, these differences determined low levels of international visibility of Colombian scientific journals, despite their increasing quality in national standards (Publindex, 2013).
\end{abstract}

The international visibility of scientific journals corresponds exclusively to the editorial process and the quality of the editorial teams. Scientific and editorial quality, stability, visibility and publications' impact in line of international standards, represent key elements to guarantee a strong position at the international level (Escobar \& Mercado, 2013).

On the other hand, the raising importance of cienciometrics to evaluate the impact of scientific publications, requires journals to be included in prestigious bibliographic databases, as the main element at the moment of their impact evaluation (Ortiz, et al., 2010).

The international visibility of scientific journals in the Colombian Caribbean region is limited (Romero, 2013), given the constant efforts and focus to national standards. These had strong implications in making visible the regional scientific production and its international recognition. By this, consolidating the editorial teams in the Caribbean region and the access to international academic networks, will improve their international position, but the most importantly will reduce the existing gaps at both the national and international levels (Escobar \& Mercado, 2013). 
The current requirements, from the international perspective, focus in Bibliographic Databases or Indexes (Bibliographic Citation Index, Bibliographic Index, and Bibliographic Databases with Selection Committee-BDSC), recognized by the National System of Indexation (Villegas, 2013). For instance, the Economic Literature Index (ECONLIT) of the American Economic Association (AEA) is listed as the only one in the economics field.

In the case of the Panorama Económico Journal, the efforts focused to increase its international visibility, and strengthening editorial processes by adopting the Open Journal System (OJS) platform. By this, during 2015 positive results were obtained and it represents the beginning of the internationalization of this journal.

At this moment, Panorama Económico is included and listed in ECONLIT of the American Economic Association (AEA), which represents the main source of economic literature worldwide. On the other hand, represent an important recognition to the editorial management process to be also listed in the European Reference Index for the Humanities (ERIH-PLUS) which requires outstanding requirements on the scientific quality set by the Standing Committee for the Humanities (SCH) of the European Science Foundation (ESF).

At the Iberoamerican level, to be included in DIALNET and REDIB (Red Iberoamericana de Innovación y Conocimiento Científico) denote major steps given that both represent the Hispanic scientific literature. To be listed in the international database FLACSO - Andes of the Facultad Latinoamericana de Ciencias Sociales allow having access at the Latin American level, due to the fact, that it is a major open access platform to disseminate, and preserve scientific resources in social sciences. With this regional emphasis, the inclusion in ACTUALIDAD IBEROAMERICANA, is another step towards an international index.
By these reasons, nowadays Panorama Económico Journal is classified at the international level, such as the CARHUS PLUS+ classification in the area of the Humanities and the Social Sciences. Similarly, it is present in the CIRC Classification (Integrated Classification of Scientific Journals in Social Sciences and Humanities) with C category and an index value of three (3). In the MIAR Initiative (Information Matrix for Journals' evaluation) developed by Universitat de Barcelona (Spain), calculate an ICDS index for Panorama Económico equals to 4,4 .

The editorial management process should focus also in participating in specialized editorial networks to exchange good practices and to consolidate work teams. For this and to continuously improve, there is an active participation in LATINOAMERICANA, an international association of academic journals in the fields of Social Sciences and Humanities. At the national level, REDITORES represent an important network of specialized journals' editors to better share successful experiences.

Finally, the main objective is to strength the international visibility through better editorial processes supported by an editorial team and the journal's Editorial Board. In the medium term, the work plan is set to be listed in Bibliographic citations indexes and impact metrics calculations (such as $\mathrm{H}$ index) in the national and international scientific community.

\section{REFERENCIAS BIBLIOGRAFICAS}

Escobar, A. \& Mercado, M. (2013), "Las Revistas Científicas Colombianas y la Política Pública de Colciencias", Panorama Económico, Vol. 22: pág. 3-5.

Ortiz, E., González, M., Infante, I. \& Viamontes, Y. (2010), "Evaluación del impacto de las tesis doctorales en Ciencias Pedagógicas mediante indicadores cienciométricos", Revista Española de Documentación Científica, 33 (2): 279-286. DOI: 10.3989/redc.2010.2.728 
Publindex (2013). Nuevo Modelo de Indexación de Publicaciones Seriadas de CTI-Publindex. Bogotá: Colciencias.

Rodríguez, A. (2014), "Infectio y las nuevas políticas de Publindex", Infectio, Vol. 18(1): 1-2.

Rodríguez, E., Naranjo, S. \& D. González (2015), "PUBLINDEX: Más que un proceso de Indexación" El Ágora, 15 (1):29-41. DOI: http:// dx.doi.org/10.21500/16578031.1

Romero, Z. (2013), "Hacia un nuevo modelo de medición que refleje las capacidades investigativas de los colombianos", Revista Saber, Ciencia y Libertad, 8(2): 13-16.

Villegas, M. (2013), "Nuevo modelo de Indexación y Homologación - Publindex: apostándole cada vez más a la visibilidad internacional", Psicología desde el Caribe, Vol. 30 (3): vii-viii. 
